Abstracta Iranica Abstracta Iranica

Revue bibliographique pour le domaine irano-aryen

Volume 23 | 2002

Comptes rendus des publications de $\mathbf{2 0 0 0}$

\title{
Ustrušanskie byli, Samarcande et Tachkent, Institut d'Archéologie, 2000, 243 p. [Histoires d'Ustrushana]
}

\section{Étienne de La Vaissière}

\section{(2) OpenEdition \\ 1 Journals}

Édition électronique

URL : http://journals.openedition.org/abstractairanica/35218

DOI : 10.4000/abstractairanica.35218

ISSN : 1961-960X

\section{Éditeur :}

CNRS (UMR 7528 Mondes iraniens et indiens), Éditions de l'IFRI

\section{Édition imprimée}

Date de publication : 15 mai 2002

ISSN : 0240-8910

\section{Référence électronique}

Étienne de La Vaissière, "Ustrušanskie byli, Samarcande et Tachkent, Institut d'Archéologie, 2000, 243 p. [Histoires d'Ustrushana] », Abstracta Iranica [En ligne], Volume 23 | 2002, document 47, mis en ligne le 08 février 2010, consulté le 25 septembre 2020. URL : http://journals.openedition.org/ abstractairanica/35218 ; DOI : https://doi.org/10.4000/abstractairanica.35218

Ce document a été généré automatiquement le 25 septembre 2020.

Tous droits réservés 


\title{
Ustrušanskie byli, Samarcande et Tachkent, Institut d'Archéologie, 2000, 243 p. [Histoires d'Ustrushana]
}

\author{
Étienne de La Vaissière
}

Comme son titre l'indique, ce livre se veut un récit d'histoires sur l'Ustrushana antique et médiéval et en ce sens ne se présente pas comme une publication scientifique. Pourtant son auteur, qui fouille plusieurs sites de caravansérails entre Džizak et Zaamin, est le meilleur spécialiste actuel de cette région de transit entre la Sogdiane, le Ferghana et le čāč et l'ouvrage peut être utile en ce qu'il rassemble et discute de nombreuses données parfois inédites, et donne quelques cartes. Une observation : l'A. tente d'établir pp. 38-53 le lien entre les deux dynasties successives qui gouvernèrent le pays du $7^{\mathrm{e}}$ au $9^{\mathrm{e}}$ s. Or l'un des documents sogdiens du Mont Mugh (A-14, 1. 20-1) montre qu'en 722 c'est le tudun du Čāč qui contrôle l'Ustrushana, et, alors que la plupart des évènements liés à la prise de Khodjent se passent en Ustrushana, aucune autre autorité que celle du tudun n'est mentionnée. L'existence de deux dynasties s'explique sans doute par cet intermède čāčĩ dans l'histoire de la région, et l'hypothèse d'un règne de Qarabughra dès 720 sur l'Ustrushana doit être révisée.

\section{INDEX}

Thèmes : 3.1. Est de l'Iran 
AUTEURS

ÉTIENNE DE LA VAISSIÈRE

ENS - Paris 